\title{
Article \\ Uncovering Real Earnings Management: Pay Attention to Risk-Taking Behavior
}

\author{
Samar Alharbi ${ }^{1}$, Md Al Mamun ${ }^{2, *}$ and Nader Atawnah ${ }^{3}$ \\ 1 College of Administrations and Finance, Saudi Electronic University, Riyadh 13323, Saudi Arabia; \\ smo.alharbi@seu.edu.sa \\ 2 Department of Economics, Finance, and Marketing, La Trobe University, Melbourne, VIC 3086, Australia \\ 3 School of Business and Law, Edith Cowan University, Joondalup, WA 6027, Australia; n.atawnah@ecu.edu.au \\ * Correspondence: m.almamun@latrobe.edu.au
}

Citation: Alharbi, Samar, $\mathrm{Md} \mathrm{Al}$

Mamun, and Nader Atawnah. 2021

Uncovering Real Earnings

Management: Pay Attention to

Risk-Taking Behavior. International

Journal of Financial Studies 9: 53.

https://doi.org/10.3390/ijfs9040053

Academic Editor: Sabri Boubaker

Received: 16 August 2021

Accepted: 17 September 2021

Published: 23 September 2021

Publisher's Note: MDPI stays neutral with regard to jurisdictional claims in published maps and institutional affiliations.

Copyright: (c) 2021 by the authors. Licensee MDPI, Basel, Switzerland. This article is an open access article distributed under the terms and conditions of the Creative Commons Attribution (CC BY) license (https:// creativecommons.org/licenses/by/ $4.0 /)$.

\begin{abstract}
We examine the impact of corporate risk-taking on firm-level real earnings management. We find that firms with higher risk-taking engage in higher real earnings management. Our results are robust to a series of robustness tests, including simultaneous least squares approach, firm fixed effect, change analysis, and pseudo difference-in-difference analysis. Additional analyses reveal that the impact of risk-taking on real earnings management is more pronounced among firms that experience prior-year loss and are run by top-echelons who are risk lovers. Sarbanes-Oxley Act (SOX) regulation does not attenuate the positive effect of risk-taking on real earnings management. However, external monitoring by institutional investors and takeover susceptibility curb the relation between risk-taking and real earnings management. Our study highlights that outsider, such as investors and regulators, should pay close attention to a firm's risk-taking behavior to unravel the extent of real earnings management in the firm.
\end{abstract}

Keywords: agency theory; corporate governance; risk-taking; real earnings management

JEL Classification: G1; G3; K2; M1; M4

\section{Introduction}

Firms engage in real earnings management (hereafter REM) activities using subtle manipulation in price discounts to inflate sales, and overproduction to under-report the cost of goods sold (Roychowdhury 2006). REM activities achieve the aim of avoiding reporting losses (Roychowdhury 2006) or inflating share price before seasoned equity offering (Cohen and Zarowin 2010). Since the passage of the SOX in 2002, REM activities have increased (Cohen et al. 2008) possibly because they are difficult for external parties to uncover (Graham et al. 2005). Given how difficult it is for external parties to detect REM (Cohen et al. 2008), we examine whether a firm's past risk-taking behavior can signal its future level of REM activities.

Prior literature extensively examines the determinants of a firm's risk-taking behavior ${ }^{1}$. However, we focus on a relatively little-known area, i.e., the consequences of risk-taking behavior. Studying the consequences of risk-taking behavior is particularly important since prior literature suggests that risk-averse top management should be encouraged to take risks to resolve underinvestment problems (Guay 1999). Awarding option incentives to top management, as heavily practiced over the past two decades, has become one of the most common mechanisms to encourage risk-taking behavior. However, yesterday's solution becomes today's problem, particularly when risk-taking activities are driven by managerial compensation targets, not by the merit or experience to handle risk nor by the opportunity to maximize firm value. Accordingly, risk-taking managers are more likely to engage in REM to achieve their compensation benchmark (Billings et al. 2020) by signaling a good performance outcome to the market. 
Furthermore, the success and failure of risky investments in the real world are equally distributed. There is no guarantee that a risky project will result in a profitable outcome. Hence, risk-taking is likely to be associated with both success and failure. Moreover, a firm's management that shows a propensity for undertaking higher risk ventures tend to understate the investment risk (Hirshleifer et al. 2012), and overstate their abilities, as well as the net present value (NPV) of the risky investment they initiate. Such behavior further necessitates managers to resort to earnings manipulation. Accordingly, we argue that resorting to REM is one possible way to cover the potential failure of risky investment.

We investigate corporate risk-taking as a potential determinant of REM using a large sample of firm-level data from 1980 to 2015 in US settings. Using two measures of firms' risk-taking, we find that risk-taking is positively related to REM. The rationale for this behavior is that higher risk-taking is associated with greater investment failure or success, which induces managers to engage in more earnings management to signal their abilities to market participants. Our results hold using industry median risk-taking as a potential instrument to conduct a two-stage least squares (2SLS) regression. Furthermore, we run firm fixed effect regression to control for all time-invariant firm-related unobservable variables in our model. We also run a year-on-year change analysis to provide further robustness of the main result. Finally, we conducted a pseudo difference-in-difference analysis with a treatment group consisting of firms that experienced a $50 \%$ increase in the risk-taking measure in a particular year against a control group that does not experience such a large increase in risk-taking measures. The rationale for considering such a change as a shock to the risk-taking variable is built on the fact that while an increase in risktaking can be caused by managerial choice, a large increase in yearly risk by more than $50 \%$ is unlikely to be a result of managerial decisions. Using such shock in risk-taking, we find that firms that experience an extremely large increase in risk-taking engage in a significantly higher level of REM in the post increase period compared to the pre increase period, controlling for control firms that do not experience such an increase in risk-taking. In all robustness tests, we find that the results are consistent with our baseline findings.

In additional analyses, we document that the joint effect of risk-taking and ex-post loss has a positive and significant effect on REM. We also find that the effect of risktaking on REM is positive and significant after controlling for prior year loss. Collectively, these results suggest that while risk-taking activities that result in operating loss further motivate managers to resort to REM, the prior-year loss alone does not explain the effect of risk-taking on REM. We also find that CEO overconfidence further aggravates the effect of risk-taking on REM. These findings are consistent with Chen et al. (2014) and Malmendier and Tate (2008), who find overconfident managers engage in higher risktaking due to underestimating risks and overestimating the expected net present value of investments. We also find that the Sarbanes-Oxley Act (SOX) does not alleviate the effect of risk-taking on REM, indicating relative inefficacy of the SOX Act in containing REM. Finally, external corporate governance mechanisms-institutional ownership and takeover susceptibility-have a dampening effect on the link between risk-taking and REM. These results are consistent with the fact that external monitoring curbs the ability of managers to reduce the quality of information disclosed to the market (Chung et al. 2002; Atawnah et al. 2018).

We contribute to the literature in three ways. First, prior studies mainly focus on the determinants and perceptions of risk-taking behavior (Schoemaker 1993; Laeven and Levine 2009; Calvet and Sodini 2014; Faccio et al. 2016). However, we contribute to the little-known evidence on the consequences of the firm's risk-taking behavior. We show that that yesterday's solution to the managerial underinvestment problem creates today's unintended new consequences in the form of real earnings management. Our findings suggest that observing the managerial risk-taking behavior can provide market participants reasonable understanding of the extent of the potential of REM activities in the firm, which is otherwise very difficult for an outsider to uncover (Cohen et al. 2008). 
Second, while a rich body of literature documents the determinants of accrual-based earnings management ${ }^{2}$, the literature on the determinants of REM is relatively limited. We extend previous literature and provide evidence that risk-taking positively explains REM. In this regard, our findings also relate to the literature on the consequence of the compensation structure aimed to promote risk-taking behavior (Bergstresser and Philippon 2006; Coles et al. 2006).

Third, our study broadens our understanding of the implications of risk-taking behavior on financial reporting quality in general and REM in particular. It also adds to the regulatory debate about the effectiveness of external monitoring and SOX regulation. Particularly with SOX regulation, we find that the effect of risk-taking on REM is not attenuated by SOX regulation. In contrast, we find that external monitoring proxied by institutional investors and takeover susceptibility curb the effect of risk-taking behavior and REM. Our paper also sheds new light on the conditions stimulating the baseline effect by documenting that firm prior-year loss and CEO overconfidence strengthen the established relationship, while prior-year loss alone does not drive our result. Finally, our study is particularly significant given the importance of real earnings management and reporting quality for making an informed decision by equity markets and external debt contracting.

The rest of this study is organized as follows. In Section 2, we develop our hypotheses. Section 3 describes our research design. Section 4 reports the main results, additional analyses, and role of corporate governance. Section 5 concludes.

\section{Literature and Hypothesis}

Dichev et al. (2013) find that managers engage in earnings management to avoid unfavorable effects on career and compensation. Recently, Li and Thibodeau (2019) show that managers manipulate earnings when the CSR rating is low, and when their compensation is CSR-contingent. Additionally, outside and inside pressure for managers to hit earnings benchmarks may lead to earnings management to influence stock prices. Further, CFOs believe that it is challenging for outside observers to uncover earnings management, especially when they are managed using real actions (Dichev et al. 2013). Cohen et al. (2008) document that in the post-SOX period, firms switched from accrual-based to real earnings management methods since SOX regulation has made it difficult to engage in accrual-based earnings management.

Given how difficult it is for outsiders to uncover real earnings management, prior research attempted to investigate the determinants of real earnings management. Baker et al. (2019) document that real earnings management is greater when the CEO is more powerful relative to $\mathrm{CFO}$ in both pre-SOX and post-SOX periods. In terms of governance, Zhao et al. (2012) document that less takeover protection is associated with higher levels of real earnings management. Cheng et al. (2016) also examine the role of firms' internal governance and find that the extent of real earnings management decreases with the horizon of key subordinate executives' and influence. Chi et al. (2011) document that auditors' industry expertise, higher audit fees, and longer auditor tenure are associated with higher levels of real earnings management.

The literature also focuses on the role of firm types in explaining real earnings management. Achleitner et al. (2014) document that family firms use earnings management activities strategically by avoiding real earnings management that inhibits the firm's longterm value. Similarly, Haga et al. (2018) document that public firms employ more real earnings management as a proportion of the total earnings management strategy. However, the prior literature is silent on how one corporate action can influence another corporate action, i.e., how risk-taking can influence real earnings management has not been studied in the previous literature.

The possible link between risk-taking and real earnings management is based on several intuitive arguments. Firstly, risk-taking is critical for a firm's value creation. For example, redesigning the compensation structure with option incentives to encourage risk-taking is a primary vehicle to overcome managerial underinvestment problems that 
compromise firm value. Accordingly, managers engage in risk-taking investment when boards of directors encourage risk-averse managers to overcome the underinvestment problem by providing higher option incentive compensation (Coles et al. 2006). Consistent with the career concern hypothesis, compensation design that incentivizes risk-taking is likely to motivate managers in REM since managers would like to signal better performance to the board and the market. Similarly, a firm's success in innovation is also a function of its risk-taking behavior (Chen et al. 2014). However, the product market success of innovation (risky investment) is uncertain and takes time to yield a positive result. Hence, managers may resort to earnings management, particularly REM, since it is difficult for outsiders to uncover.

Secondly, in the real world, risk-taking would probably lead to higher earnings volatility as the success and failure of risky projects are evenly poised. Faced with such uncertainty or the desire to smooth earnings, managers are more likely to resort to REM, as accrual-based earnings management is difficult to execute in today's heightened financial reporting regulatory environment (Cohen et al. 2008).

Thirdly, Naldi et al. (2007) document that risk-taking is negatively related to performance. Given that corporate risk-taking is a product of top management's overconfidence or hubris, it results in managerial underestimation of risks and overestimation of the expected net present value of their investment (Malmendier and Tate 2008). In reality, when the project ends up yielding less than what is expected, managers partake in earnings management. Alternatively, faced with risk-taking-driven poor performance, managers are more likely to engage in real earnings management. Taken together, we test the following hypothesis:

Hypothesis 1 (H1). Corporate risk-taking is positively related to real earnings management (REM).

\section{Research Design}

\subsection{Measures of Risk-Taking}

We use two measures of risk-taking. First, we follow John et al. (2008) and measure the Fama and French 49 industry adjusted average of company risk-taking proxy as per the below formula

$$
\text { RISK1 }=\sqrt{\frac{\mathrm{T}}{\mathrm{T}-1} \sum_{\mathrm{T}-1}^{\mathrm{T}}\left(\mathrm{E}_{\mathrm{i}, \mathrm{s}, \mathrm{t}}-\frac{1}{\mathrm{~T}} \sum_{\mathrm{t}=1}^{\mathrm{T}} \mathrm{E}_{\mathrm{i}, \mathrm{s}, \mathrm{t}}\right)^{2}} ; \mathrm{T} \geq 5
$$

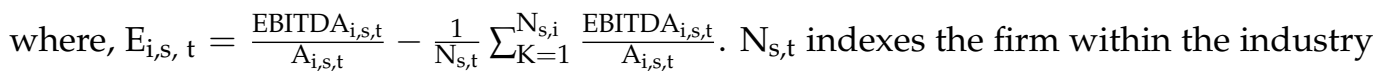
in year $t$. EBITDA $A_{i, s, t}$ is defined as depreciation plus operating income after depreciation. $\mathrm{A}_{\mathrm{i}, \mathrm{s}, \mathrm{t}}$ is the contemporaneous assets. We require at least five-year available earnings to total assets to calculate our industry-adjusted firm's risk-taking proxy. Second, we use a five-year rolling standard deviation of return on assets as our second measure of risk-taking (RISK2).

\subsection{Measure of Real Earnings Management}

Following Roychowdhury (2006), we use abnormal discretionary expenses, the residual from the following cross-sectional model as our measure of real earnings management (REM). ${ }^{3}$

$$
\operatorname{DEXP}_{i, t} / \mathrm{A}_{i, t-1}=\mu_{0}+\mu_{1}\left(1 / \mathrm{A}_{i, t-1}\right)+\mu_{2}\left(\mathrm{R}_{i t}-1 / \mathrm{A}_{i, t-1}\right)+\varepsilon_{i, t}
$$

In the model, $\mathrm{DEXP}_{i, t}$ is the discretionary expenses summing together $\mathrm{R} \& \mathrm{D}$, advertising, and selling, general and administrative expenses of firm $i$ in year $t$. Following Ali and Zhang (2015), if selling, general, and administrative expense is available, and R\&D and advertising expenses are missing, these two expenses are set to zero. $\mathrm{A}_{i, t-1}$ is the total asset of firm $i$ at the beginning of year $t$, while $\mathrm{R}_{i, t-1}$ is the sales revenue of firm $i$ in year $t-1$. Following Roychowdhury (2006), we drop firm-year observation if both sales and total assets are less than USD 10 million, and share price is less than USD 1. 


\subsection{The Empirical Model}

We employ the following regression model to examine the effect of firm risk-taking behavior on real earnings management.

$$
\operatorname{REM}_{i t}=\beta_{0}+\beta_{1} * \text { Risk-taking }_{i, t-1}+\beta_{2} * \operatorname{Controls}_{i, t-1}+\text { Year FE }+ \text { Industry FE }+\varepsilon_{i, t}
$$

where $\mathrm{REM}_{i, t}$ is the real earnings management, and risk-taking are RISK1 and RISK2 (see Sections 3.1 and 3.2 for measurements). We include several control variables identified in the literature to be related to real earnings management. We control for leverage (LEV), size (SIZE), market to book (MTB) ratio, ROE, net operating assets (NOA), sales growth (SG), cash flow from operation (CFO), acquisition dummy (AQCD), and analyst following (LNANAL) (Barton and Simko 2002; Cheng and Warfield 2005; Roychowdhury 2006; Cohen et al. 2008; Piotroski and Roulstone 2004). Lastly, since earnings management varies across industries and over time, we include year and industry-fixed effects in our model. We correct standard errors for clustering at the firm level. Detailed variable definitions are available in Appendix A.

\subsection{Sample Selection}

We obtain a total of 190,434 firm-year observations from Compustat for the period 1980 to 2015 to construct our variables. Following Roychowdhury (2006) and dropping firms in finance and regulated utility industries, we generate a sample of 77,888 non-missing firm-level observations for REM, risk-taking, and control variables. To alleviate the issue of reverse causality and simultaneity, we use the dependent variable at time $t$, and the main independent and all control variables are at time $t-1$. To control for potential outliers, all variables (except dummy variables) were winsorized at $1 \%$ levels (Zaman et al. 2021a). Appendix A provides detailed variable definitions.

\section{Results and Discussion}

\subsection{Descriptive Statistics and Correlation}

Table 1 presents descriptive statistics of risk-taking, REM, and control variables for our sample firms. The mean of RISK1 and RISK2 are 0.122 and 0.135 , respectively. This is comparable with John et al. (2008). The mean of REM is -0.082 comparable with Ali and Zhang (2015). The average firm in our sample has a leverage ratio of 0.168 and total assets of about USD 210 million (with a natural logarithm value of 5.345). The mean MTB ratio is 1.598 while the median is 1.101, indicating a cross-sectional difference among our sample firms. All other firm-specific control variables such as SIZE, ROE, LEV, etc., are consistent with prior literature (Ali and Zhang 2015).

To rule out any multicollinearity issue, we conducted a Pearson correlation test and present the result in Table 2 . The correlation between RISK $1_{t-1}$ and $R E M_{t}$ is 0.3411 $(p<0.000), \operatorname{RISK}_{\mathrm{t}-1}$, and $\mathrm{REM}_{\mathrm{t}}$ are $0.2834(p<0.000)$, suggesting an initial indication of a positive relationship between risk-taking and REM. The correlations among the right-hand side variables are generally low, indicating no serious multicollinearity concerns. 
Table 1. Summary statistics.

\begin{tabular}{ccccccc}
\hline Variables & $\mathbf{N}$ & Mean & St. dev & $\mathbf{2 5 \%}$ & Median & $\mathbf{7 5 \%}$ \\
\hline REM & 77,888 & -0.082 & 0.443 & -0.303 & -0.137 & 0.037 \\
RISK1 & 77,888 & 0.122 & 0.171 & 0.036 & 0.066 & 0.132 \\
RISK2 & 77,888 & 0.135 & 0.479 & 0.026 & 0.055 & 0.118 \\
LEV & 77,888 & 0.068 & 0.160 & 0.000 & 0.016 & 0.067 \\
SIZE & 77,888 & 5.345 & 2.273 & 3.668 & 5.349 & 6.961 \\
MTB & 77,888 & 1.598 & 1.945 & 0.760 & 1.101 & 1.760 \\
ROE & 77,888 & 0.004 & 1.017 & -0.046 & 0.081 & 0.167 \\
NOA & 77888 & 8.772 & 27.127 & 1.936 & 3.375 & 6.374 \\
SG & 77,888 & 0.005 & 0.404 & -0.050 & 0.058 & 0.156 \\
CFO & 77,888 & 0.052 & 0.240 & 0.012 & 0.080 & 0.142 \\
AQCD & 77,888 & 0.965 & 0.183 & 1.000 & 1.000 & 1.000 \\
LNANAL & 77,888 & 0.588 & 0.891 & 0.000 & 0.000 & 1.269
\end{tabular}

This table presents the summary statistics of the sample observations. The sample period covers the period 1980 to 2015. Variable definitions are in Appendix A. All variables, except dummies, are winsorized at a $1 \%$ level.

Table 2. Correlation matrix.

\begin{tabular}{cccccccc}
\hline & & $\mathbf{1}$ & $\mathbf{2}$ & $\mathbf{3}$ & $\mathbf{4}$ & $\mathbf{5}$ & $\mathbf{6}$ \\
\hline REM & 1 & 1 & & & & & \\
RISK1 & 2 & 0.3411 & 1 & & & & \\
RISK2 & 3 & 0.2834 & 0.4643 & 1 & & & \\
LEV & 4 & 0.1006 & 0.2381 & 0.1982 & 1 & & \\
SIZE & 5 & -0.2277 & -0.3882 & -0.2216 & -0.1662 & 1 & 1 \\
MTB & 6 & 0.2858 & 0.2935 & 0.2108 & 0.0815 & -0.1424 & 0.0119 \\
ROE & 7 & -0.0414 & -0.0574 & -0.0385 & 0.0183 & 0.0968 & -0.0331 \\
NOA & 8 & -0.0455 & -0.0306 & -0.0034 & -0.0263 & -0.0398 & 0.0412 \\
SG & 9 & 0.0079 & -0.1535 & -0.0104 & -0.0103 & 0.1722 & -0.2274 \\
CFO & 10 & -0.2707 & -0.4281 & -0.3716 & -0.2857 & 0.3254 & -0.0183 \\
AQCD & 11 & 0.0146 & 0.0254 & 0.0081 & -0.0096 & -0.1191 & 0.0554 \\
LNANAL & 12 & -0.0701 & -0.1699 & -0.0956 & -0.1438 & 0.5554 & $\mathbf{1 2}$ \\
\hline & & $\mathbf{7}$ & $\mathbf{8}$ & $\mathbf{9}$ & $\mathbf{1 0}$ & $\mathbf{1 1}$ & \\
\hline ROE & 7 & 1 & & & & & \\
NOA & 8 & -0.0202 & 1 & & & & \\
SG & 9 & 0.0514 & -0.0465 & 1 & & & \\
CFO & 10 & 0.1247 & 0.0133 & 0.13 & 1 & & \\
AQCD & 11 & -0.0059 & 0.0151 & -0.0281 & -0.0112 & 1 & \\
LNANAL & 12 & 0.0295 & -0.016 & 0.0741 & 0.168 & -0.0806 & 1
\end{tabular}

This table presents the correlation matrix for the variable under study. The sample period is from 1980 to 2015 . This table only reports correlation significance at the $1 \%$ level.

\subsection{Baseline Results}

We estimate Equation (1) to examine the impact of firm risk-taking behavior on real earnings managers and report the results in Table 3. In columns (1) and (2), we regress our measure of real earnings management (REM) on both measures of risk-taking (RISK1 and RISK2) and include all the firm-level control variables, together with year and industry fixed effects. 
Table 3. Risk-taking and real earnings management—baseline results.

\begin{tabular}{|c|c|c|}
\hline & \multicolumn{2}{|c|}{ Real Earnings Management $\left(R E M_{t}\right)$} \\
\hline & Model (1) & Model (2) \\
\hline$R I S K 1_{t-1}$ & $\begin{array}{c}0.587^{* * *} \\
(15.99)\end{array}$ & \\
\hline$R I S K 2_{t-1}$ & & $\begin{array}{c}0.156^{* * *} \\
(8.82)\end{array}$ \\
\hline$L E V_{t-1}$ & $\begin{array}{l}-0.043 \\
(-1.47)\end{array}$ & $\begin{array}{l}-0.014 \\
(-0.45)\end{array}$ \\
\hline$S I Z E_{t-1}$ & $\begin{array}{c}-0.016^{* * *} \\
(-8.61)\end{array}$ & $\begin{array}{c}-0.024^{* * *} \\
(-11.88)\end{array}$ \\
\hline$M T B_{t-1}$ & $\begin{array}{c}0.040^{* * *} \\
(8.68)\end{array}$ & $\begin{array}{c}0.044^{* * *} \\
(9.76)\end{array}$ \\
\hline$R O E_{t-1}$ & $\begin{array}{l}-0.004 \\
(-1.24)\end{array}$ & $\begin{array}{l}-0.004 \\
(-1.29)\end{array}$ \\
\hline$N O A_{t-1}$ & $\begin{array}{c}-0.000^{* * * *} \\
(-2.59)\end{array}$ & $\begin{array}{c}-0.000 * * * \\
(-3.91)\end{array}$ \\
\hline$S G_{t-1}$ & $\begin{array}{c}0.069 * * * \\
(9.66)\end{array}$ & $\begin{array}{c}0.041^{* * *} \\
(6.02)\end{array}$ \\
\hline$C F O_{t-1}$ & $\begin{array}{c}-0.220^{* * *} \\
(-6.50)\end{array}$ & $\begin{array}{c}-0.236^{* * *} \\
(-7.14)\end{array}$ \\
\hline$A Q C D_{t-1}$ & $\begin{array}{l}0.004 \\
(0.41)\end{array}$ & $\begin{array}{l}0.004 \\
(0.35)\end{array}$ \\
\hline$L_{N A N A L S T} T_{t-1}$ & $\begin{array}{l}0.007^{*} \\
(1.95)\end{array}$ & $\begin{array}{l}0.007^{*} \\
(1.85)\end{array}$ \\
\hline Constant & $\begin{array}{l}-0.025 \\
(-1.26)\end{array}$ & $\begin{array}{c}0.041^{* *} \\
(2.09)\end{array}$ \\
\hline Year FE & Yes & Yes \\
\hline Industry FE & Yes & Yes \\
\hline Observations & 77,888 & 77,888 \\
\hline Adjusted R-square & 0.2539 & 0.2442 \\
\hline $\begin{array}{l}\text { Table } 3 \text { presents the effect of the } \\
\text { real earnings management bas } \\
\text { variable is at year } t \text {. The mai } \\
\text { are reported in parentheses ar } \\
\text { regressions. The } 1 \%, 5 \% \text {, and } 1 \\
\text { Variable definitions are provid }\end{array}$ & $\begin{array}{l}\text { RISK1 and R } \\
\text { iscretionary } \\
\text { riables and } c \\
\text {. Both indus } \\
\text { els of the coe }\end{array}$ & $\begin{array}{l}\text { lanagement. } \\
\text { ry 2006). The } \\
\text { year } t-1 . \\
\text { ts are includ } \\
* * * * * \text { and } * \text {, }\end{array}$ \\
\hline
\end{tabular}

The results in Table 3 show that firm risk-taking behavior is positively related to real earnings management. Specifically, the coefficient estimates on RISK1 and RISK2 are 0.587 and 0.156 , respectively, and are statistically significant at the $1 \%$ level. These results are not only statistically significant but also have important economic significance. For example, one standard deviation increase in RISK 1 at time $t-1$ increases REM by $22.65 \%$ $(=0.587 * 0.171 / 0.443)$ at time $t$. The result is similar in our second model as well. Our results indicate that outsiders can learn about firms' real earnings management by observing the risk-taking behavior of the managers. This is because engaging in risk-taking behavior is associated with potentially higher levels of success and failure, which entices managers to engage in more earnings management to paint a rosier picture of their performance to stakeholders.

We find that the coefficient of LEV is negative, indicating that firms exposed to higher monitoring by lenders reduce REM activities. The coefficient of MTB is positive and significant, showing that growth firms tend to spend more on R\&D and can maneuver higher REM (Roychowdhury 2006). We find that larger firms tend to engage in lower REM (Yu 2008). The coefficient of other control variables is consistent with prior literature (Ali and Zhang 2015). Overall, the results support our hypothesis. ${ }^{4}$ 


\subsection{Addressing Endogeneity}

In this section, we attempt to address potential endogeneity concerns regarding the relationship between firm risk-taking and real earnings management. The concern is that firm's management may jointly determine the equilibrium level of risk-taking and real-earnings management. Although our use of a dependent variable at time $t$ and independent and control variables at time $t-1$ potentially mitigate the simultaneous or joint determination of risk-taking and real earnings management, it does not however entirely mitigate the endogeneity problem arising from other sources of variations. Hence, we use three strategies in an attempt to alleviate endogeneity concerns.

First, we utilize the two least squares regression (2SLS) using the industry median of risk-taking as an instrumental variable (IV). Firm risk-taking is likely to be influenced by its peers in the same industry as firms compete in their industry for market share and investment opportunities. However, it is less likely to have a direct impact on a firm's REM. Hence, we performed the IV regression in two stages. In the first stage, we regress each measure of firm risk-taking (RISK1 and RISK2) on our instrumental variable (MEDIAN-Risk) by including other firm-level control variables akin to our baseline model and firm-fixed effects. In the second stage, we estimate the regression model in Equation (1) but replace both measures of risk-taking with the predicted values from the first-stage regression. We present the results in Table 4.

Table 4. Risk-taking and real earnings management-robustness check.

\begin{tabular}{|c|c|c|c|c|}
\hline \multicolumn{5}{|c|}{ Panel A: Two-stage least square (2SLS). } \\
\hline & \multicolumn{2}{|c|}{ First Stage } & \multicolumn{2}{|c|}{ Second Stage } \\
\hline & Risk1 & Risk2 & Real Earnings & ement $\left(R E M_{t}\right)$ \\
\hline & (Model 1) & (Model 2) & (Model 3) & (Model 4) \\
\hline MEDIAN-Risk & $\begin{array}{c}0.298 * * * \\
(5.61)\end{array}$ & $\begin{array}{c}0.114^{* * *} \\
(3.33)\end{array}$ & & \\
\hline PredRisk & & & $\begin{array}{c}0.859^{* * *} \\
(5.41)\end{array}$ & $\begin{array}{c}0.842^{* * *} \\
(7.49)\end{array}$ \\
\hline$L E V_{t-1}$ & $\begin{array}{c}0.026^{* *} \\
(2.38)\end{array}$ & $\begin{array}{c}0.153^{* * *} \\
(3.99)\end{array}$ & $\begin{array}{l}-0.052 * \\
(-1.67)\end{array}$ & $\begin{array}{c}-0.095^{* * *} \\
(-2.67)\end{array}$ \\
\hline$S I Z E_{t-1}$ & $\begin{array}{c}-0.019^{* * *} \\
(-9.55)\end{array}$ & $\begin{array}{c}-0.032 * * * \\
(-6.66)\end{array}$ & $\begin{array}{l}-0.005 \\
(-1.17)\end{array}$ & $\begin{array}{l}0.001 \\
(0.29)\end{array}$ \\
\hline$M T B_{t-1}$ & $\begin{array}{c}0.004^{* * *} \\
(4.33)\end{array}$ & $\begin{array}{c}0.017^{* * *} \\
(5.86)\end{array}$ & $\begin{array}{c}0.039^{* * *} \\
(7.83)\end{array}$ & $\begin{array}{c}0.033^{* * *} \\
(6.14)\end{array}$ \\
\hline$R O E_{t-1}$ & $\begin{array}{l}-0.000 \\
(-0.14)\end{array}$ & $\begin{array}{l}-0.000 \\
(-0.06)\end{array}$ & $\begin{array}{l}-0.005 \\
(-1.38)\end{array}$ & $\begin{array}{l}-0.003 \\
(-1.04)\end{array}$ \\
\hline$N O A_{t-1}$ & $\begin{array}{c}-0.000^{* * *} \\
(-3.48)\end{array}$ & $\begin{array}{l}-0.000 \\
(-1.17)\end{array}$ & $\begin{array}{c}-0.000^{* *} \\
(-2.01)\end{array}$ & $\begin{array}{c}-0.000^{* *} \\
(-2.47)\end{array}$ \\
\hline$S G_{t-1}$ & $\begin{array}{c}-0.010^{* * * *} \\
(-4.67)\end{array}$ & $\begin{array}{c}0.045^{* * *} \\
(6.07)\end{array}$ & $\begin{array}{c}0.067^{* * * *} \\
(8.66)\end{array}$ & $\begin{array}{l}0.010 \\
(1.22)\end{array}$ \\
\hline$C F O_{t-1}$ & $\begin{array}{c}-0.045^{* * *} \\
(-5.77)\end{array}$ & $\begin{array}{c}-0.347^{* * *} \\
(-9.35)\end{array}$ & $\begin{array}{c}-0.214^{* * *} \\
(-5.60)\end{array}$ & $\begin{array}{l}-0.031 \\
(-0.59)\end{array}$ \\
\hline$A Q C D_{t-1}$ & $\begin{array}{l}0.000 \\
(0.18)\end{array}$ & $\begin{array}{l}0.000 \\
(0.04)\end{array}$ & $\begin{array}{l}0.001 \\
(0.14)\end{array}$ & $\begin{array}{l}0.001 \\
(0.09)\end{array}$ \\
\hline$L_{N A N A L S T} T_{t-1}$ & $\begin{array}{c}-0.002^{* * *} \\
(-2.69)\end{array}$ & $\begin{array}{l}-0.001 \\
(-0.57)\end{array}$ & $\begin{array}{c}0.008^{* *} \\
(2.17)\end{array}$ & $\begin{array}{c}0.006 \\
(1.58)\end{array}$ \\
\hline Constant & $\begin{array}{c}0.190^{* * *} \\
(8.82)\end{array}$ & $\begin{array}{c}0.458^{* * *} \\
(4.41)\end{array}$ & $\begin{array}{c}-0.103^{* * *} \\
(-2.79)\end{array}$ & $\begin{array}{c}-0.166^{* * *} \\
(-4.62)\end{array}$ \\
\hline Year FE & Yes & Yes & Yes & Yes \\
\hline Industry FE & Yes & Yes & Yes & Yes \\
\hline Observations & 77,888 & 77,888 & 77,888 & 77,888 \\
\hline Adjusted R-square & 0.4635 & 0.542 & 0.2471 & 0.2252 \\
\hline
\end{tabular}


Table 4. Cont.

\begin{tabular}{|c|c|c|}
\hline \multicolumn{3}{|c|}{ Panel B: Firm fixed effect. } \\
\hline & \multicolumn{2}{|c|}{ Real Earnings Management $\left(R E M_{t}\right)$} \\
\hline & Model (1) & Model (2) \\
\hline$R I S K 1_{t-1}$ & $\begin{array}{c}0.317 \text { *** } \\
(8.45)\end{array}$ & \\
\hline$R I S K 2_{t-1}$ & & $\begin{array}{c}0.139^{* * * *} \\
(6.70)\end{array}$ \\
\hline$L E V_{t-1}$ & $\begin{array}{l}0.021 \\
(0.65)\end{array}$ & $\begin{array}{l}0.025 \\
(0.81)\end{array}$ \\
\hline$S I Z E_{t-1}$ & $\begin{array}{c}0.009 * \\
(1.74)\end{array}$ & $\begin{array}{l}0.001 \\
(0.20)\end{array}$ \\
\hline$M T B_{t-1}$ & $\begin{array}{c}0.022^{* * *} \\
(7.35)\end{array}$ & $\begin{array}{c}0.023^{* * *} \\
(7.48)\end{array}$ \\
\hline$R O E_{t-1}$ & $\begin{array}{l}-0.002 \\
(-0.60)\end{array}$ & $\begin{array}{l}-0.001 \\
(-0.53)\end{array}$ \\
\hline$N O A_{t-1}$ & $\begin{array}{l}0.000 \\
(0.85)\end{array}$ & $\begin{array}{l}0.000 \\
(0.46)\end{array}$ \\
\hline$S G_{t-1}$ & $\begin{array}{c}0.031^{* * *} \\
(4.29)\end{array}$ & $\begin{array}{c}0.022^{* * *} \\
(3.18)\end{array}$ \\
\hline$C F O_{t-1}$ & $\begin{array}{l}-0.082 * * \\
(-2.43)\end{array}$ & $\begin{array}{l}-0.060 * \\
(-1.73)\end{array}$ \\
\hline$A Q C D_{t-1}$ & $\begin{array}{c}0.020 * * * \\
(2.64)\end{array}$ & $\begin{array}{c}0.021^{* * *} \\
(2.69)\end{array}$ \\
\hline$L_{N A N A L S T_{t-1}}$ & $\begin{array}{c}-0.023^{* * * *} \\
(-8.46)\end{array}$ & $\begin{array}{c}-0.023^{* * *} \\
(-8.73)\end{array}$ \\
\hline Constant & $\begin{array}{c}-0.084^{* * *} \\
(-3.00)\end{array}$ & $\begin{array}{l}-0.036 \\
(-1.34)\end{array}$ \\
\hline Year FE & Yes & Yes \\
\hline Industry FE & No & No \\
\hline Firm FE & Yes & Yes \\
\hline Observations & 77,888 & 77,888 \\
\hline Adjusted R-square & 0.6506 & 0.6535 \\
\hline \multicolumn{3}{|c|}{ Panel C: Change regression. } \\
\hline & \multicolumn{2}{|c|}{$\Delta$ Real Earnings Management $\left(R E M_{t}\right)$} \\
\hline & Model (1) & Model (2) \\
\hline$\Delta R I S K 1_{t-1}$ & $\begin{array}{c}1.165^{* * *} \\
(7.00)\end{array}$ & \\
\hline$\Delta R I S K 2_{t-1}$ & & $\begin{array}{c}1.050^{* * *} \\
(5.32)\end{array}$ \\
\hline$\Delta L E V_{t-1}$ & $\begin{array}{l}0.089 \\
(0.70)\end{array}$ & $\begin{array}{l}0.083 \\
(0.66)\end{array}$ \\
\hline$\Delta S I Z E_{t-1}$ & $\begin{array}{l}-0.022 \\
(-1.22)\end{array}$ & $\begin{array}{l}-0.030 * \\
(-1.67)\end{array}$ \\
\hline$\Delta M T B_{t-1}$ & $\begin{array}{c}0.026^{*} \\
(1.85)\end{array}$ & $\begin{array}{c}0.029 * * \\
(2.02)\end{array}$ \\
\hline$\Delta R O E_{t-1}$ & $\begin{array}{l}-0.009 \\
(-1.03)\end{array}$ & $\begin{array}{l}-0.008 \\
(-0.99)\end{array}$ \\
\hline$\Delta N O A_{t-1}$ & $\begin{array}{l}0.002 \\
(1.59)\end{array}$ & $\begin{array}{l}0.001 \\
(1.14)\end{array}$ \\
\hline$\Delta S G_{t-1}$ & $\begin{array}{c}-0.126^{* * *} \\
(-4.08)\end{array}$ & $\begin{array}{c}-0.142^{* * *} \\
(-4.61)\end{array}$ \\
\hline$\Delta C F O_{t-1}$ & $\begin{array}{c}0.189 * * \\
(1.97)\end{array}$ & $\begin{array}{c}0.186 * \\
(1.92)\end{array}$ \\
\hline$\triangle A Q C D_{t-1}$ & $\begin{array}{c}0.139 * * * \\
(2.69)\end{array}$ & $\begin{array}{c}0.140^{* * *} \\
(2.73)\end{array}$ \\
\hline$\Delta L_{N A N A L S T} T_{t-1}$ & $\begin{array}{l}-0.020 \\
(-0.82)\end{array}$ & $\begin{array}{l}-0.022 \\
(-0.90)\end{array}$ \\
\hline
\end{tabular}


Table 4. Cont.

\begin{tabular}{|c|c|c|}
\hline \multicolumn{3}{|c|}{ Panel C: Change regression. } \\
\hline & \multicolumn{2}{|c|}{$\Delta$ Real Earnings Management $\left(R E M_{t}\right)$} \\
\hline & Model (1) & Model (2) \\
\hline Constant & $\begin{array}{l}0.198 \\
(1.52)\end{array}$ & $\begin{array}{l}0.162 \\
(1.25)\end{array}$ \\
\hline Year FE & Yes & Yes \\
\hline Industry FE & Yes & Yes \\
\hline Observations & 77,888 & 77,888 \\
\hline Adjusted R-square & 0.1395 & 0.1389 \\
\hline \multicolumn{3}{|c|}{ Panel D: Large increase in risk-taking and pseudo-difference-in-difference analysis. } \\
\hline $\begin{array}{l}\text { Based on Risk } \\
\quad \text { Measures }\end{array}$ & RISK1 & RISK2 \\
\hline \multirow{2}{*}{ Dependent Variable } & \multicolumn{2}{|c|}{ Real earnings management $\left(R E M_{t}\right)$} \\
\hline & Model (1) & Model (2) \\
\hline TREAT*POST & $\begin{array}{c}0.021 * * \\
(2.13)\end{array}$ & $\begin{array}{c}0.032^{* * *} \\
(3.12)\end{array}$ \\
\hline TREAT & $\begin{array}{c}-0.019 \text { ** } \\
(-2.50)\end{array}$ & $\begin{array}{c}-0.032^{* * *} \\
(-4.31)\end{array}$ \\
\hline POST & $\begin{array}{l}-0.004 \\
(-0.61)\end{array}$ & $\begin{array}{l}-0.008 \\
(-0.97)\end{array}$ \\
\hline Constant & $\begin{array}{c}0.059 * * \\
(2.17)\end{array}$ & $\begin{array}{c}0.082^{* * *} \\
(3.12)\end{array}$ \\
\hline Baseline controls & Yes & Yes \\
\hline Year FE & Yes & Yes \\
\hline Firm FE & Yes & Yes \\
\hline Observations & 35,567 & 35,567 \\
\hline Adjusted R-square & 0.2235 & 0.2202 \\
\hline
\end{tabular}

This table reports regression results for the relationship between a firm's risk-taking (RISK1 and RISK2) on real earnings management using alternative estimations that account for endogeneity. Panel A of Table 4 reports the second stage results of 2SLS regression. Panel B reports the firm fixed effect regression. Panel C presents the change-on-change analysis. Panel D presents the pseudo difference-in-difference analysis using large increase in risk-taking variable. We construct real earnings management based on abnormal discretionary expenses (Roychowdhury 2006). The dependent variable is at year $t$. The main independent variables and control variables are at year $t-1$. The $t$-values are reported in parentheses and clustered by firm. The $1 \%, 5 \%$, and $10 \%$ significance levels of the coefficients are denoted by ${ }^{* * *},{ }^{* *}$, and $*$, respectively. All variables, except the dummy variables, are winsorized at $1 \%$. Variable definitions are provided in Appendix A.

The first stage results presented in columns (1) and (2) of Panel A show that industry median risk-taking (MEDIAN-Risk) is positively and significantly related to firm risktaking. More importantly, the coefficient estimates on predicted risk-taking (PredRisk) in the second stage (columns (3) and (4)) are positive and significant at a $1 \%$ level, implying that firm risk-taking behavior increases the level of firm real earnings management.

Second, we run firm fixed effects regression to address the concern that our result is driven by firm-related omitted variable bias or other unobservable variables that are not captured in our model. The firm fixed effects regression accounts for all time-invariant firm-level characteristics that might be associated with both the left and right-hand side variables (Thompson 2011), i.e., the level of firm risk-taking and REM. We estimate our baseline Equation 1 using a firm fixed-effect model and present the results in Panel B of Table 4 . The qualitatively similar findings to our baseline results suggest that a positive relationship between risk-taking and real earnings management is not influenced by any time-invariant firm characteristics.

Third, we employ a change regression to relate the year-by-year change in REM to year-by-year changes in risk-taking (Zaman et al. 2021b). We calculate the change values by taking the first differences, i.e., the difference between $t$ and $t-1$ for the dependent variable and changes between $t-1$ and $t-2$ for independent and control variables. The 
change analysis differences away the cross-sectional variation in firms, allowing us to focus on the time-series variation. Consequently, this approach also potentially resolves the reverse causality and further alleviates the concern of omitted variable bias. The change analysis results in Panel $\mathrm{C}$ of Table 4 are consistent with our main results.

Finally, we use a large increase in firms' risk-taking behavior as a setting for conducting a pseudo difference-in-difference analysis. To do so, we generate a sample of treatment and control firms based on a large increase in our risk-taking variables and create a TREAT variable. Specifically, the TREAT variable takes the value of 1 if the yearly percentage change in RISK1 and RISK2 variables for a firm is more than $50 \%$ and 0 for matched control firms with similar characteristics that do not experience such a large increase in both measures of risk-taking. We match treatment firm and control firms at time $t-1$ based on baseline control variables. Since we observed that some firms in our sample experience an increase in risk-taking by more than $50 \%$ multiple times, we only consider the first-time increase in our sample. The intuition behind considering such a large increase in risk-taking measures is that while an increase in risk-taking can be caused by managerial choice, a large increase in yearly risk by more than $50 \%$ is unlikely to be a result of managerial decisions. Rather, such a large increase is more likely to be caused by exogenous factors. Next, we create a dummy variable POST, that takes the value of 1 for periods following a large increase in RISK1 and RISK2 measures for our treated firms and the corresponding periods for our control firms. In contrast, the POST variable takes the value of 0 for the periods before a large increase in RISK1 and RISK2 measures for our treated firms and corresponding periods for our control firms. Finally, we create an interaction variable of TREAT * POST and run our baseline model with this restricted sample by replacing our RISK1 and RISK2 measure with TREAT, POST, and TREAT * POST variables. We present the result in Panel D of Table 4. We find that the variable TREAT * POST has a statistically positive and significant effect on REM irrespective of whether we construct our TREAT and POST variable based on RISK1 or RISK2 measures. Our result suggests that firms that experience an extremely large increase in risk-taking engage in a significantly higher level of REM in the post increase period compared to the pre increase period, controlling for control firms that do not experience such a high level of increase in $\mathrm{REM}^{5}$. Overall, the results presented in Table 4 that aim to address endogeneity concerns are consistent with the baseline results in Table 3 .

\subsection{Additional Tests}

One of the primary motives for engaging in REM is to cover the operating loss of the firm (Cohen et al. 2008). Since operating loss can result from higher risk-taking, one would find that the effect of risk-taking on REM would magnify when the firm faces operating losses. To test this notion, we capture a firm's operating loss with a dummy variable $\left(\operatorname{LOSSD}_{t-1)}\right.$ that equals one if the firm reports a net loss and zero otherwise. We then interact both risk-taking measures with our operating loss dummy variable and re-estimate our baseline model (Equation (1)). We present the results in Table 5.

The result in Panel A of Table 5 shows that the joint effect of risk-taking and operating loss dummy (RISK1*LOSSD ${ }_{t-1}$ and RISK2* ${ }^{*} \operatorname{LSSD}_{t-1}$ ) on REM is positive and significant at the $1 \%$ level. Our result highlights that a firm that has experienced operating loss in the past year is likely to reverse that performance, at least on paper, by engaging in more REM when such a loss is related to prior risky investment. 
Table 5. Risk-taking and real earnings management-additional tests.

\begin{tabular}{|c|c|c|}
\hline \multicolumn{3}{|c|}{ Panel A: Risk-taking, operating loss, and real earnings management. } \\
\hline & \multicolumn{2}{|c|}{ Real earnings management $\left(R E M_{t}\right)$} \\
\hline & Model (1) & Model (2) \\
\hline$R I S K 1_{t-1}$ & $\begin{array}{l}0.465^{* * *} \\
(8.02)\end{array}$ & \\
\hline$R I S K 2_{t-1}$ & & $\begin{array}{l}0.086^{* * *} \\
(3.41)\end{array}$ \\
\hline RISK1*LOSSD ${ }_{t-1}$ & $\begin{array}{c}0.185^{* * *} \\
(2.82)\end{array}$ & \\
\hline$R I S K 2 * L^{* S S} D_{t-1}$ & & $\begin{array}{c}0.093^{* * *} \\
(2.88)\end{array}$ \\
\hline $\operatorname{LOSSD}_{t-1}$ & $\begin{array}{c}-0.028^{* * *} \\
(-3.25)\end{array}$ & $\begin{array}{c}0.011^{*} \\
(1.68)\end{array}$ \\
\hline Constant and baseline controls & Yes & Yes \\
\hline Year FE & Yes & Yes \\
\hline Industry FE & Yes & Yes \\
\hline Observations & 77,888 & 77,888 \\
\hline Adjusted $\mathrm{R}^{2}$ & 0.2548 & 0.2462 \\
\hline \multicolumn{3}{|c|}{ Panel B: Risk-taking, overconfident CEOs, and real earnings management. } \\
\hline & Model (1) & Model (2) \\
\hline$R I S K 1_{t-1}$ & $\begin{array}{c}0.276^{* * *} \\
(3.90)\end{array}$ & \\
\hline$R I S K 2_{t-1}$ & & $\begin{array}{c}0.185^{* * *} \\
(3.11)\end{array}$ \\
\hline RISK1 $^{*} H O L D 100_{t-1}$ & $\begin{array}{c}0.263 * * \\
(2.18)\end{array}$ & \\
\hline RISK2* HOLD $100_{t-1}$ & & $\begin{array}{c}0.327^{* * *} \\
(3.38)\end{array}$ \\
\hline$H O L D 100_{t-1}$ & $\begin{array}{l}-0.018 * \\
(-1.77)\end{array}$ & $\begin{array}{l}-0.019^{* *} \\
(-2.24)\end{array}$ \\
\hline Constant and baseline controls & Yes & Yes \\
\hline Year FE & Yes & Yes \\
\hline Industry FE & Yes & Yes \\
\hline Observations & 77,888 & 77,888 \\
\hline
\end{tabular}

\begin{tabular}{ccccc}
\hline \multicolumn{4}{c}{77,888} & \multicolumn{3}{c}{77,888} \\
\hline & Panel C: Risk-taking, firm size, and real earnings management. & \\
\hline & High Size & Low Size & High Size & Low Size \\
\hline RISK1 $1_{t-1}$ & $0.652^{* * *}$ & $0.246^{* * *}$ & & \\
RISK2 ${ }_{t-1}$ & $(15.69)$ & $(5.63)$ & & \\
& & & $0.157^{* * *}$ & $0.117^{* * *}$ \\
Constant & & & $(8.58)$ & $(3.02)$ \\
& $-0.159^{* * *}$ & $-0.131^{* * *}$ & $-0.125^{* * *}$ & $-0.125^{* * *}$ \\
Constant and baseline controls & $(-5.29)$ & $(-6.46)$ & $(-4.07)$ & $(-6.23)$ \\
Year FE & Yes & Yes & Yes & Yes \\
Industry FE & Yes & Yes & Yes & Yes \\
Observations & Yes & Yes & Yes & Yes \\
Adjusted $R^{2}$ & 38,944 & 38,944 & 38,944 & 38,944 \\
& 0.2314 & 0.2812 & 0.2163 & 0.2809
\end{tabular}

This table presents three panels. Panel A presents the joint effect of risk-taking (RISK1 and RISK2) and loss dummy $(L O S S D)$ on real earnings management. Panel B reports the joint effect of risk-taking and CEO overconfidence (HOLD100) on real earnings management. Panel C presents the role of firm size in the link between risk-taking and real earnings management. The t-values reported in parentheses are clustered by firm. The $1 \%, 5 \%$, and $10 \%$ significance levels of the coefficients are denoted by ${ }^{* * *}, * *$, and $*$, respectively. Variable definitions are provided in Appendix A. 
Next, we test the moderating effect of overconfident managers in our baseline result. This is because prior studies show that overconfident managers generally engage in overinvestment and higher risk-taking (Chen et al. 2014). They also tend to overvalue the ex-post negative NPV projects as value-creating and are more likely to stick to negative NPV projects, ignoring the feedback. The evidence that overconfident CEOs provide more optimistic earnings forecasts (Hilary and Hsu 2011; Hribar and Yang 2016) may necessitate them managing their earnings more than non-overconfident CEOs. Hence, the effect of risk-taking on REM is likely to be more prominent in firms with overconfident CEOs. To test our conjecture, we use an option-based measure of CEO overconfidence (HOLD100), which is a dummy variable that equals one for overconfident CEOs and zero otherwise. Specifically, we follow Campbell et al. (2011) to construct our CEO overconfidence measure. We classify CEOs as overconfident if they hold options at least twice during the sample period of more than $100 \%$ in the money. Our measure of CEO overconfidence, HOLD100, takes the value of one if a CEO holds options that are more than $100 \%$ in the money for at least two years and zero otherwise. We then interact both risk-taking measures with our dummy variable (HOLD100) and re-estimate our baseline model (Equation (1)). The results in Panel B of Table 5 show that the positive and significant effect of risk-taking on REM is stronger in firms with overconfident CEO.

Finally, we conduct a subsample test using firm size. This is because the prior literature suggests that firm size is one of the key variables that affects the firm's decisions and outcomes (Coles and Li 2019). Although we have controlled for size in our main regression, further examination of firm size in our context is critical. It is plausible that large firms can diversify risk and are less likely to manipulate earnings, including real earning management. Hence, we performed an additional test using a subsampling strategy based on firm size. Specifically, we create a firm size dummy variable that takes the value of one if the firm size is higher than the sample median firm size and otherwise zero. We present the result in Panel C of Table 5. The results show that the effect of risk-taking on REM is positive and significant in both high and low size firms. However, consistent with our contention, we find that the impact of risk-taking on REM is more prominent in small size firms compared to higher size firms ${ }^{6}$.

\subsection{Role of Governance}

Sarbanes-Oxley Act (SOX) 2002 reduced accounting flexibility for firms to engage in accrual-based earnings management techniques (Cohen et al. 2008). Zang (2012) documents that managers use REM as a substitute for accrual-based earnings management, and vice versa. Hence, we argue that higher risk-taking firms are likely to engage more in REM post-SOX to achieve important earnings forecast benchmarks. Using SOX dummy (SOXD) to separate between pre- and post-SOX periods, we find that the joint effect of risk-taking and SOXD (RISK1*SOXD $t_{t-1}$ and RISK2*SOXD ${ }_{t-1}$ ) has a positive and significant impact on REM (Panel A of Table 6). Hence, SOX does not weaken the positive impact of risk-taking on REM.

The prior literature documents that the external corporate governance mechanisms also affect the level of earnings manipulation (Xie et al. 2003; Mouselli and Hussainey 2014). To test this conjecture, we use institutional ownership (IO) and takeover index (TOIND) as two proxies of corporate governance. We define institutional ownership (IO) as the total number of shares held by institutional investors divided by the total shares outstanding (Alharbi et al. 2020). The takeover index (TOIND) is developed by Cain et al. (2017), constructed from external legal determinants that are effective for the market for corporate control. We then interact each governance measure with firm risk-taking measures and re-estimate our baseline model (Equation (1)). Using both measures of external monitoring, the results in Panel B and C of Table 6 suggest that the joint impacts of IO (TOIND) and risk-taking on REM are negative and significant. These findings suggest that external monitoring mechanisms are effective in mitigating REM for a firm that engages in higher risk-taking behavior. 
Table 6. Risk-taking and real earnings management-role of governance.

\begin{tabular}{|c|c|c|}
\hline \multicolumn{3}{|c|}{ Panel A: Risk-taking, SOX regulation, and real earnings management. } \\
\hline & \multicolumn{2}{|c|}{ Real earnings management $\left(R E M_{t}\right)$} \\
\hline & Model (1) & Model (2) \\
\hline$R I S K 1_{t-1}$ & $\begin{array}{c}0.486^{* * *} \\
(10.94)\end{array}$ & \\
\hline$R I S K 2_{t-1}$ & & $\begin{array}{c}0.103^{* * *} \\
(5.59)\end{array}$ \\
\hline RISK1*SOXD ${ }_{t-1}$ & $\begin{array}{l}0.178^{* * *} \\
(3.03)\end{array}$ & \\
\hline$R I S K 2 * S O X D_{t-1}$ & & $\begin{array}{l}0.560 * * * \\
(9.19)\end{array}$ \\
\hline$S O X D_{t-1}$ & $\begin{array}{l}-0.199 * * * \\
(-11.82)\end{array}$ & $\begin{array}{l}-0.214^{* * *} \\
(-13.18)\end{array}$ \\
\hline Constant and baseline controls & Yes & Yes \\
\hline Year FE & Yes & Yes \\
\hline Industry FE & Yes & Yes \\
\hline Observations & 77,888 & 77,888 \\
\hline Adjusted $\mathrm{R}^{2}$ & 0.2550 & 0.2564 \\
\hline
\end{tabular}

Panel B: Risk-taking, institutional ownership, and real earnings management.

\begin{tabular}{ccc}
\hline & Model (1) & Model (2) \\
\hline$R I S K 1_{t-1}$ & $0.598^{* * *}$ & \\
$R I S K 2_{t-1}$ & $(10.42)$ & $0.240^{* * *}$ \\
& & $(5.16)$ \\
$R I S K 1^{*} I O_{t-1}$ & $-0.356^{* * *}$ & \\
$R I S K 2^{*} I O_{t-1}$ & $(-3.52)$ & $-0.071^{* *}$ \\
$I O_{t-1}$ & & $(-2.50)$ \\
& $0.041^{* * *}$ & 0.013 \\
Constant and baseline controls & $(3.61)$ & $(1.46)$ \\
Year FE & Yes & Yes \\
Industry FE & Yes & Yes \\
Observations & Yes & 77,888 \\
Adjusted $R^{2}$ & 77,888 & 0.2392 \\
\hline
\end{tabular}

Panel C: Risk-taking, hostile takeover index, and real earnings management.

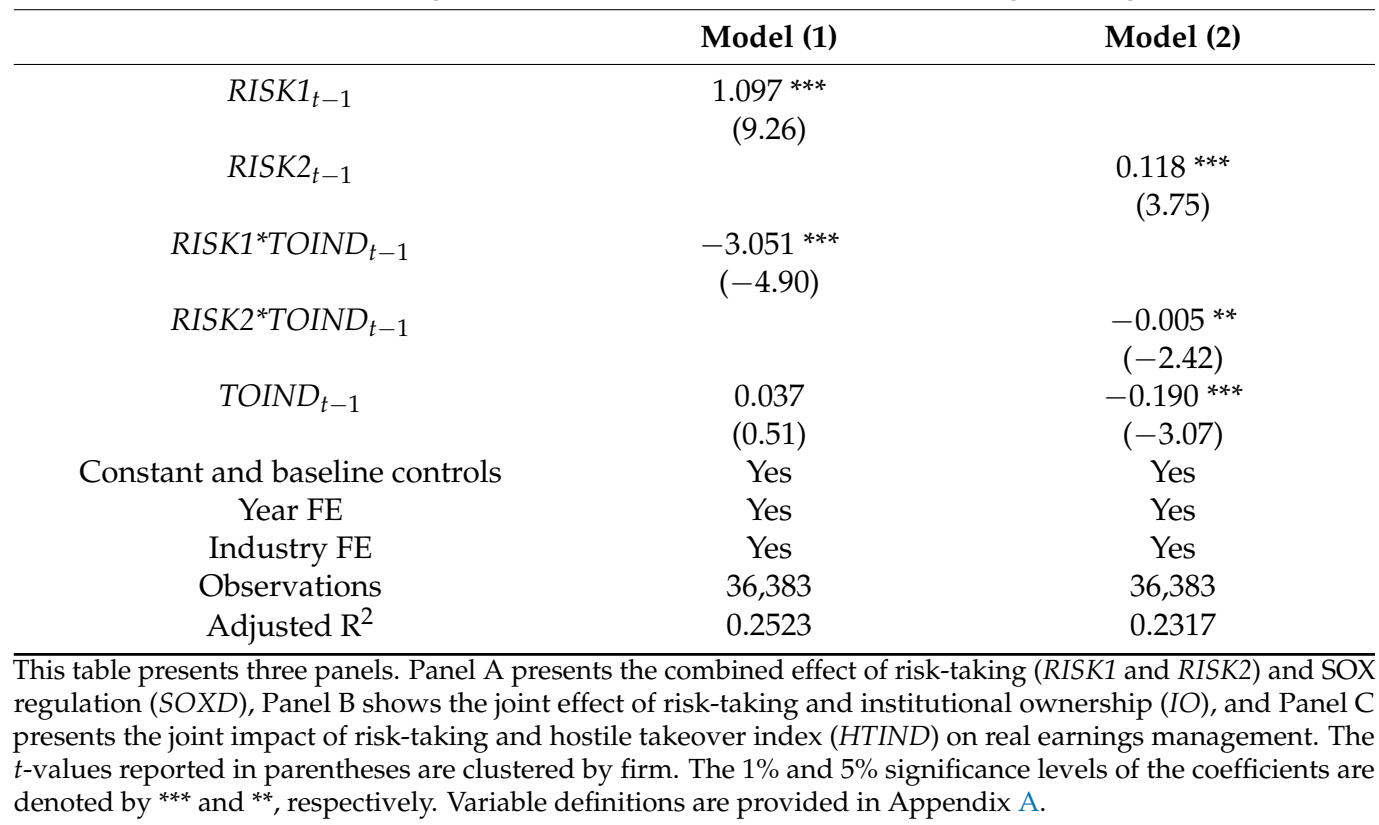




\section{Conclusions}

Our paper examines whether market participants can learn about the magnitude of real earnings management activities engaged by a firm's managers by observing its risktaking activities. Utilizing a large sample of US companies, we provide evidence that firms that undertake more risk-taking behavior today engage in a higher level of real earnings management tomorrow. We adopt several methods in an attempt to mitigate potential endogeneity concerns. First, we use a two-stage least squares (2SLS) approach. Second, we use the firm fixed effect. Third, we employ the change-on-change analysis. Finally, we conduct a pseudo-DiD analysis with a treatment group consists of firms that experienced a $50 \%$ increase in the risk-taking measure in a particular year against a control group of firms that does not experience such a large increase in risk-taking measures. In all three tests, we find support for our baseline results that firms with high risk-taking behavior engage in more earnings management. However, we caution the readers about any inference drawn from these tests collectively since they do not establish causality. At the least, these tests present a more robust link between risk-taking and real earnings management.

In an additional analysis, we find that prior year reporting loss and CEO overconfidence significantly magnify the relation between risk-taking and REM. However, the result is not solely driven by firms that experience a loss or by small firms. Additionally, we find that the SOX regulation does not attenuate the relation between risk-taking and REM. However, a higher level of external monitoring by takeover susceptibility and institutional ownership does.

Our study makes important contributions. The prior literature mainly focuses on the determinants of risk-taking, while we examine the implication of risk-taking and document it as a determinant of REM. More importantly, while the prior literature presents risktaking as a solution to the underinvestment problem, we show that encouraging a higher level of risk-taking may create unintended negative consequences, i.e., a higher level of real earnings management (REM). The findings of our study allow market participants a simpler tool to learn about the REM activities of firms, which is otherwise known to be difficult for external parties to uncover. Overall, our findings are likely to be beneficial to regulators, investors, and lenders who rely on the quality of information disclosed by the firm to make informed decisions.

Finally, our result is drawn from firms in the US setting with robust and rich regulatory settings. Hence, our result may not be generalizable for other markets where institutional, regulatory, and cultural settings might present different levels of incentives or challenges for managers in engaging in risky corporate behavior. Future research can be undertaken to understand the generality of our findings in the context of other markets.

Author Contributions: Conceptualization, M.A.M.; methodology, M.A.M. and N.A.; software, M.A.M. and S.A.; validation, M.A.M. and N.A.; formal analysis, M.A.M. and S.A.; investigation, M.A.M., N.A. and S.A.; resources, M.A.M., N.A. and S.A.; data curation, S.A.; writing-original draft preparation, M.A.M.; writing—review and editing, M.A.M. and N.A.; supervision, M.A.M. and N.A.; project administration, M.A.M. and N.A. All authors have read and agreed to the published version of the manuscript.

Funding: This research received no external funding.

Institutional Review Board Statement: Not applicable.

Informed Consent Statement: Not applicable.

Data Availability Statement: Available at paid WRDS database.

Conflicts of Interest: The authors declare no conflict of interest. 


\section{Appendix A}

Table A1. Variable Description.

\begin{tabular}{|c|c|}
\hline Dependent Variables & Description \\
\hline REM & $\begin{array}{l}\text { Real earnings management is the abnormal discretionary expenses of firm } i \text { in year } t \text {, estimated as the } \\
\text { residual of the discretionary expenses by Roychowdhury (2006) for real earnings management. }\end{array}$ \\
\hline \multicolumn{2}{|r|}{ Risk Independent Variables } \\
\hline RISK1 & $\begin{array}{l}\text { Following John et al. (2008), RISK is the five years standard deviation of the firm's EBITDA/Assets from } \\
\text { FF49 industry average EBITDA/Assets for the corresponding year. }\end{array}$ \\
\hline RISK2 & The standard deviation of NI to total assets of the firm over the last five years period. \\
\hline \multicolumn{2}{|r|}{ Firm's Independent Variables } \\
\hline$L E V$ & Total debt divided by total assets at the beginning of year $t$. \\
\hline SIZE & Natural logarithm of total sales revenue. \\
\hline MTB & The market value of equity is divided by the book value of equity at the beginning of year $t$. \\
\hline$R O E$ & Return on assets is net income divided by common/ordinary equity. \\
\hline NOA & $\begin{array}{l}\text { Net operating asset at the beginning of year } t \text {, defined as shareholders' equity minus cash and } \\
\text { marketable securities, plus total debt, and deflated by sales. }\end{array}$ \\
\hline$S G$ & Log transformation of sales divided by prior year sales. \\
\hline CFO & Cash flow from operations in year $t$ is scaled by the total assets at the beginning of year $t$. \\
\hline$A Q C D$ & $\begin{array}{c}\text { An indicator variable that equals one if the firm has engaged in a merger and acquisition in year } t \text {, and } \\
\text { zero otherwise. }\end{array}$ \\
\hline LNANAL & Natural logarithm of an average number of analysts following the firm over the year. \\
\hline \multicolumn{2}{|r|}{ Robustness Variables } \\
\hline LOSSD & Dummy variable that equals to one for firm reports a net loss for year $t$, otherwise zero. \\
\hline HOLD100 & $\begin{array}{l}\text { An option-based measure of CEO overconfidence. Indicator variable equals } 1 \text { for all years after a CEO } \\
\text { holds options that are } 100 \% \text { in the money, and } 0 \text { otherwise. }\end{array}$ \\
\hline$R D$ & $\begin{array}{c}\text { Research and development expenditure scaled by the book value of total assets. Missing values coded } \\
\text { with } 0 \text {. }\end{array}$ \\
\hline \multicolumn{2}{|r|}{ Governance Variables } \\
\hline IO & Percentage of stocks held by institutional investors at the beginning of year $t$. \\
\hline TOIND & Hostile takeover index, a measure of takeover susceptibility suggested by (Cain et al. 2017). \\
\hline SOXD & Dummy variable that equals one for post-SOX periods, otherwise zero. \\
\hline
\end{tabular}

\section{Notes}

1 Studies includes managerial perception towards risk (MacCrimmon and Wehrung 1990), market concentration and power (Jiménez et al. 2013), managerial ownership and compensation (Coles et al. 2006), corporate governance (Acharya et al. 2011), and SOX regulation (Bargeron et al. 2010), etc.

2 Earnings management is influenced by leverage buyouts (Mao and Renneboog 2015), CEO tenure (Ali and Zhang 2015), CEO turnover (Hazarika et al. 2012); unemployment insurance (Dou et al. 2016), geographical dispersion (Shi et al. 2015), CEO and CFO equity incentives (Jiang et al. 2010), corporate governance (Cornett et al. 2009), diversification (Rodríguez-Pérez and Hemmen 2010), audit committee effort (Caramanis and Lennox 2008), and audit committee expertise (Badolato et al. 2014), etc.

3 We use two-digit SIC industry-year group level requiring at least 10 observations for each industry-year group for the estimation (Ali and Zhang 2015).

4 To ensure that our baseline results are not driven by firms that experience a loss, in untabulated results we controlled for the prior-year loss. The effect of risk-taking on earnings management remains significant at the $1 \%$ level. We are thankful to the anonymous reviewer for this suggestion.

5 We thank the Editor for suggesting this test.

6 We thank the anonymous reviewer for suggesting to us that we further study and rationalize our study in the context of firm size.

\section{References}

Acharya, Viral, Yakov Amihud, and Lubomir Litov. 2011. Creditor rights and corporate risk-taking. Journal of Financial Economics 102: 150-66. [CrossRef]

Achleitner, Ann-Kristin, Nina Günther, Christoph Kaserer, and Gianfranco Siciliano. 2014. Real earnings management and accrualbased earnings management in family firms. European Accounting Review 23: 431-61. [CrossRef] 
Alharbi, Samar, Nader Atawnah, Md Al Mamun, and Muhammad Jahangir Ali. 2020. Local culture and tax avoidance: Evidence from gambling preference behavior. Global Finance Journal 100585. [CrossRef]

Ali, Ashiq, and Weining Zhang. 2015. CEO tenure and earnings management. Journal of Accounting and Economics 59: 60-79. [CrossRef]

Atawnah, Nader, Balasingham Balachandran, Huu Nhan Duong, and Edward J. Podolski. 2018. Does exposure to foreign competition affect stock liquidity? Evidence from industry-level import data. Journal of Financial Markets 39: 44-67. [CrossRef]

Badolato, Patrick G., Dain C. Donelson, and Matthew Ege. 2014. Audit committee financial expertise and earnings management: The role of status. Journal of Accounting and Economics 58: 208-30. [CrossRef]

Baker, Terry A., Thomas J. Lopez, Austin L. Reitenga, and George W. Ruch. 2019. The influence of CEO and CFO power on accruals and real earnings management. Review of Quantitative Finance and Accounting 52: 325-45. [CrossRef]

Bargeron, Leonce L., Kenneth M. Lehn, and Chad J. Zutter. 2010. Sarbanes-Oxley and corporate risk-taking. Journal of Accounting and Economics 49: 34-52. [CrossRef]

Barton, Jan, and Paul J. Simko. 2002. The balance sheet is an earnings management constraint. The Accounting Review 77: 1-27. [CrossRef]

Bergstresser, Daniel, and Thomas Philippon. 2006. CEO incentives and earnings management. Journal of Financial Economics 80: 511-29. [CrossRef]

Billings, Bruce K., James R. Moon Jr., Richard M. Morton, and Dana M. Wallace. 2020. Can Employee Stock Options Contribute to Less Risk-Taking? Contemporary Accounting Research 37: 1658-86. [CrossRef]

Cain, Matthew D., Stephen B. McKeon, and Steven Davidoff Solomon. 2017. Do takeover laws matter? Evidence from five decades of hostile takeovers. Journal of Financial Economics 124: 464-85. [CrossRef]

Calvet, Laurent E., and Paolo Sodini. 2014. Twin picks: Disentangling the determinants of risk-taking in household portfolios. The Journal of Finance 69: 867-906. [CrossRef]

Campbell, T. Colin, Michael Gallmeyer, Shane A. Johnson, Jessica Rutherford, and Brooke W. Stanley. 2011. CEO optimism and forced turnover. Journal of Financial Economics 101: 695-712. [CrossRef]

Caramanis, Constantinos, and Clive Lennox. 2008. Audit effort and earnings management. Journal of Accounting and Economics 45: 116-38. [CrossRef]

Chen, Yangyang, Edward J. Podolski, S. Ghon Rhee, and Madhu Veeraraghavan. 2014. Local gambling preferences and corporate innovative success. Journal of Financial and Quantitative Analysis 49: 77-106. [CrossRef]

Cheng, Qiang, and Terry D. Warfield. 2005. Equity incentives and earnings management. The Accounting Review 80: 441-76. [CrossRef]

Cheng, Qiang, Jimmy Lee, and Terry Shevlin. 2016. Internal governance and real earnings management. The Accounting Review 91: 1051-85. [CrossRef]

Chi, Wuchun, Ling Lei Lisic, and Mikhail Pevzner. 2011. Is enhanced audit quality associated with greater real earnings management? Accounting Horizons 25: 315-35. [CrossRef]

Chung, Richard, Michael Firth, and Jeong-Bon Kim. 2002. Institutional monitoring and opportunistic earnings management. Journal of Corporate Finance 8: 29-48. [CrossRef]

Cohen, Daniel A., Aiyesha Dey, and Thomas Z. Lys. 2008. Real and accrual-based earnings management in the pre and post-SarbanesOxley periods. The Accounting Review 83: 757-87. [CrossRef]

Cohen, Daniel A., and Paul Zarowin. 2010. Accrual-based and real earnings management activities around seasoned equity offerings. Journal of Accounting and Economics 50: 2-19. [CrossRef]

Coles, Jeffrey L., and Zhichuan Frank Li. 2019. An Empirical Assessment of Empirical Corporate Finance. Available online: https:/ / ssrn.com/abstract=1787143 or http:/ / dx.doi.org/10.2139/ssrn.1787143 (accessed on 15 June 2021).

Coles, Jeffrey L., Naveen D. Daniel, and Lalitha Naveen. 2006. Managerial incentives and risk-taking. Journal of Financial Economics 79: 431-68. [CrossRef]

Cornett, Marcia Millon, Jamie John McNutt, and Hassan Tehranian. 2009. Corporate governance and earnings management at large US bank holding companies. Journal of Corporate Finance 15: 412-30. [CrossRef]

Dichev, Ilia D., John R. Graham, Campbell R. Harvey, and Shiva Rajgopal. 2013. Earnings quality: Evidence from the field. Journal of Accounting and Economics 56: 1-33. [CrossRef]

Dou, Yiwei, Mozaffar Khan, and Youli Zou. 2016. Labor unemployment insurance and earnings management. Journal of Accounting and Economics 61: 166-84. [CrossRef]

Faccio, Mara, Maria-Teresa Marchica, and Roberto Mura. 2016. CEO gender, corporate risk-taking, and the efficiency of capital allocation. Journal of Corporate Finance 39: 193-209. [CrossRef]

Graham, John R., Campbell R. Harvey, and Shiva Rajgopal. 2005. The economic implications of corporate financial reporting. Journal of Accounting and Economics 40: 3-73. [CrossRef]

Guay, Wayne R. 1999. The sensitivity of CEO wealth to equity risk: An analysis of the magnitude and determinants. Journal of Financial Economics 53: 43-71. [CrossRef]

Haga, Jesper, Henrik Höglund, and Dennis Sundvik. 2018. Stock market listing status and real earnings management. Journal of Accounting and Public Policy 37: 420-35. [CrossRef]

Hazarika, Sonali, Jonathan M. Karpoff, and Rajarishi Nahata. 2012. Internal corporate governance, CEO turnover, and earnings management. Journal of Financial Economics 104: 44-69. [CrossRef] 
Hilary, Gilles, and Charles Hsu. 2011. Endogenous overconfidence in managerial forecasts. Journal of Accounting and Economics 51: 300-13. [CrossRef]

Hirshleifer, David, Angie Low, and Siew Hong Teoh. 2012. Are overconfident CEOs better innovators? The Journal of Finance 67: 1457-98. [CrossRef]

Hribar, Paul, and Holly Yang. 2016. CEO overconfidence and management forecasting. Contemporary Accounting Research 33: 204-27. [CrossRef]

Jiang, John Xuefeng, Kathy R. Petroni, and Isabel Yanyan Wang. 2010. CFOs and CEOs: Who has the most influence on earnings management? Journal of Financial Economics 96: 513-26. [CrossRef]

Jiménez, Gabriel, Jose A. Lopez, and Jesús Saurina. 2013. How does competition affect bank risk-taking? Journal of Financial Stability 9: 185-95. [CrossRef]

John, Kose, Lubomir Litov, and Bernard Yeung. 2008. Corporate governance and risk-taking. The Journal of Finance 63: 1679-728. [CrossRef]

Laeven, Luc, and Ross Levine. 2009. Bank governance, regulation and risk taking. Journal of Financial Economics 93: 259-75. [CrossRef]

Li, Zhichuan Frank, and Caleb Thibodeau. 2019. CSR-contingent executive compensation incentive and earnings management. Sustainability 11: 3421. [CrossRef]

MacCrimmon, Kenneth R., and Donald A. Wehrung. 1990. Characteristics of risk-taking executives. Management Science 36: 422-35. [CrossRef]

Malmendier, Ulrike, and Geoffrey Tate. 2008. Who makes acquisitions? CEO overconfidence and the market's reaction. Journal of Financial Economics 89: 20-43. [CrossRef]

Mao, Yaping, and Luc Renneboog. 2015. Do managers manipulate earnings prior to management buyouts? Journal of Corporate Finance 35: 43-61. [CrossRef]

Mouselli, Sulaiman, and Khaled Hussainey. 2014. Corporate governance, analyst following, and firm value. Corporate Governance 14: 453-66. [CrossRef]

Naldi, Lucia, Mattias Nordqvist, Karin Sjöberg, and Johan Wiklund. 2007. Entrepreneurial orientation, risk-taking, and performance in family firms. Family Business Review 20: 33-47. [CrossRef]

Piotroski, Joseph D., and Darren T. Roulstone. 2004. The influence of analysts, institutional investors, and insiders on the incorporation of market, industry, and firm-specific information into stock prices. The Accounting Review 79: 1119-51. [CrossRef]

Rodríguez-Pérez, Gonzalo, and Stefan Van Hemmen. 2010. Debt, diversification and earnings management. Journal of Accounting and Public Policy 29: 138-59. [CrossRef]

Roychowdhury, Sugata. 2006. Earnings management through real activities manipulation. Journal of Accounting and Economics 42: 335-70. [CrossRef]

Schoemaker, Paul J. H. 1993. Determinants of risk-taking: Behavioral and economic views. Journal of Risk and Uncertainty 6: 49-73. [CrossRef]

Shi, Guifeng, Jianfei Sun, and Rui Luo. 2015. Geographic dispersion and earnings management. Journal of Accounting and Public Policy 34: 490-508. [CrossRef]

Thompson, Samuel B. 2011. Simple formulas for standard errors that cluster by both firm and time. Journal of Financial Economics 99: 1-10. [CrossRef]

Xie, Biao, Wallace N. Davidson III, and Peter J. DaDalt. 2003. Earnings management and corporate governance: The role of the board and the audit committee. Journal of Corporate Finance 9: 295-316. [CrossRef]

Yu, Fang Frank. 2008. Analyst coverage and earnings management. Journal of Financial Economics 88: 245-71. [CrossRef]

Zaman, Rashid, Nader Atawnah, Ghasan A. Baghdadi, and Jia Liu. 2021a. Fiduciary duty or loyalty? Evidence from co-opted boards and corporate misconduct. Journal of Corporate Finance, 102066.

Zaman, Rashid, Nader Atawnah, Muhammad Haseeb, Muhammad Nadeem, and Saadia Irfan. 2021b. Does corporate eco-innovation affect stock price crash risk? The British Accounting Review, 101031. [CrossRef]

Zang, Amy Y. 2012. Evidence on the trade-off between real activities manipulation and accrual-based earnings management. The Accounting Review 87: 675-703. [CrossRef]

Zhao, Yijiang, Kung H. Chen, Yinqi Zhang, and Michael Davis. 2012. Takeover protection and managerial myopia: Evidence from real earnings management. Journal of Accounting and Public Policy 31: 109-35. [CrossRef] 